\title{
Integrated Farming Systems: A potential Tool for Doubling Farmer's Income
}

\author{
K. Tejeswara Rao*, M. M. V. Srinivasa Rao and T. S. S. K. Patro \\ AICRP on Integrated Farming Systems, Agricultural Research Station, \\ Vizianagaram, AP, India \\ *Corresponding author
}

\section{Keywords \\ food, feed, fiber and fuel, nutritional security \\ Article Info \\ Accepted: \\ 24 August 2019 \\ Available Online: \\ 10 September 2019}

During the last 4-5 decades of agricultural research and development in India, major emphasis has been given to component and commodity based research projects for developing crop varieties, animal breeds and farm implements etc, mostly conducted in isolation and at the institute level. This component, commodity and discipline based research has proved largely inadequate in addressing the multifarious problems of small farmers. Due to such approaches, several ills have appeared in Indian farming, such as decreasing factor productivity, resource use efficiency and declining farm profitability and productivity. Environmental degradation including ground water contamination and entry of toxic substance into the food chain has become a significant problem. To tackle such problems, farming systems approaches to research has been widely recognized.

\section{Introduction}

The nature has provided us with the best kind of natural resources of land, water, climate and biodiversity to meet our food and nutritional need. However, these resources have been overexploited and overstretched during the last four decades to meet food, feed, fiber and fuel demands of ever increasing human and livestock populations.
India supports about $17 \%$ of human and $11 \%$ of livestock population of the world just on $2.8 \%$ land and $4.2 \%$ of water resources. New generation will have to produce more food with diminishing natural resource base. The issues of current concern to national food and nutritional security include: diversion of agricultural land for non-agricultural use, decreasing land holding size, declining profit margin in agriculture, depletion of ground 
water, deteriorating soil health and biodiversity, Increased frequency of climate related risks such as cyclones/tsunami, drought and floods, cold and heat waves etc; contamination of soil and water with heavy metals.

The world population has been increasing day by day by leaps and bounds. India's population is expected to reach 1370 and 1660 $\mathrm{m}$ in 2030 and $2050 \mathrm{AD}$, respectively. The country's food production has reached an all time high of $204 \mathrm{~m}$. t. during 2000. A food production level of 289 and $349 \mathrm{~m}$. t. is needed to satisfy the projected population in 2030 and $2050 \mathrm{AD}$, respectively. The net cultivable area is $142.8 \mathrm{~m}$ ha. Unlike the population spurt and corresponding food need for 2050, there is every chance that the land area under cultivation will decrease due to diversion of some of the cultivable area to buildings and industrial purposes. It is anticipated that the land area available for cultivation in 2050 would be $137 \mathrm{~m}$ ha. So, it becomes necessary to increase the productivity and it could be made possible by putting the land, both irrigated and rain fed, under intensive cultivation.

The Indian economy is predominantly rural and agriculture oriented. In agriculture, 85 per cent of the holdings are less than two hectares and the declining trend in the average size, Indian agriculture currently faces a host of divers' challenges and fresh constraints due to the ever growing population, increasing food and fodder needs, natural resources degradation, higher cost of inputs \& concerns of climate change.

A phenomenal increase in food grain production from 51 million tonners in 1950-51 to a record production of 263 million tonnes in the year 2013-14 could be achieved using improved technology including integrated farming systems. Time concept relates to increasing the intensity of cropping under assured irrigated conditions, whereas, space utilization pertains to building up of vertical dimension though multi-tier cropping and farming system approach. By adopting these two concepts, the productivity per unit area per unit time can be substantially enhanced. Farming system approach is one of the approaches wherein the risk in dealing with single component can be minimized, and at the same time increase the productivity through effective recycling.

Further scope for horizontal expansion of land for cultivation of farm enterprises, the emphasis should be on vertical expansion by increasing the productivity using the available resources properly and choosing the best enterprises. The income from cropping alone is hardly sufficient to sustain the farmer's; those constitute about $80 \%$ of agricultural population with only about $36 \%$ of area operated. With decline in farm size due to explosion of population, it would be increasingly difficult to produce enough food for the family by the end of $21^{\text {st }}$ century.

The farmers need to be assured of regular income for living at least above poverty line. In this context, farming system approach is one of the important solutions to face this peculiar situation as in farming system approach the different enterprises can be carefully undertaken and the location specific systems are developed based on available resources which will result into sustainable development. It is also a fact that highly productive lands are being diverted from agriculture to infrastructural development, urbanization and other related activities. Under these circumstances the only option is to increase the productivity vertically.

In view of these situations, Integrated Farming System is the only way through which the target could be achieved. Indian agriculture is predominantly cereal, cotton based cropping 
and other coarse millets primarily cultivated during Kharif and rabi seasons and more than $25 \%$ with non-food crops integrated with livestock activities. Rapid decline in land area for cultivation, exploding urban migration, and diversion of land area for non-agricultural purposes, declining input use efficiency, spurt in sub-division and fragmentation of landholdings, declining productivity in small and marginal holdings are some of the issues and challenges in sustaining and promoting innovative farm management practices in India. It is very important to diversify the agriculture, importance and success of integrated farming systems.

\section{Farming systems}

Farming systems refer deliberate raising of crops, forest and fruit trees, animals including fisheries, piggery and duck farming, sericulture, mushroom, on a given unit of land to increase the productivity and profitability, to upgrade natural resource base and to achieve overall improvement in the environment (Singh, 2005). The philosophy behind shifting from cropping system to the integrated farming system mode involves:

In situ recycling of organic residues including farm wastes generated at the farm to reduce the dependency on chemicals.

Decrease in cost of cultivation through enhance input use efficiency,

Effective use of bye-products / waters of one component for the benefit of other component / components

Upgrading of soil and water quality and biodiversity,

Increased water productivity,

Nutritional security
Environmental security

Continues flow of income and employment throughout the year

Faming system provides a vast canvass of livelihood gathering, a better risk coping strategy, continuous flow of income and employment throughout the year for small landholders. It involves utilization of primary and secondary produce of one system as a basic input of other system through making them mutually integrated.

\section{Concept and principles of farming systems}

The modern agriculture emphasizes two more dimensions viz, time and space concepts. Time concept relates to increasing crop intensification in situations where there is no constraint for inputs. In rain fed areas where there is no possibility of increasing the intensity of cropping, the other modern concept (space concept) can be applied. In space concept, crops are arranged in tier system combining two or more crops with varying field duration as intercrops by suitable modifying the planting method.

Income through arable cropping alone is insufficient for bulk of the marginal farmers. Activities such as dairy, poultry, fish culture, sericulture, bio-gas production, edible mushroom cultivation, agro-forestry and agrihorticulture, etc., assumes critical importance in supplementing their farm income. It should fit well with farm level infrastructure and ensures fuller utilization of bye-products. Integrated farming system is only the answer to problem of increasing food production for increasing income and for improving the nutrition of small scale farmers with limited resources. Farming system is a complex interrelated matrix of soil, plant, animal's implements power, labour capital and other. Input controlled in parts by farm families and 
influenced by varying degree of political, economic, institutional and social forces that operate at many level. Farming system is an integrated resource management strategy for obtaining economic and sustained crop and livestock production and preserving the resources base with high environmental quality. Agricultural system that integrates livestock and crop production or integrated fish or livestock and may be sometime known as integrated bio-system. In this system inter related set of enterprises use that the 'waste' from one component becomes an input for another part of the system which reduces cost and improves production and income. It involve the utilization of primary produce and secondary produce of one system as a basic input of the other system. "The crop and cropping system" based perspective of research needs to make way for "farming systems" based research conducted in a holistic manner for the sound management of available resources by small farmers (Jha,2003). With the gradual shrinking of land holding, it is necessary to integrate enterprises like livestock, dairy (fishery, poultry, duckery) apiary, field and horticultural crops, etc. within the bio-physical and socio-economic environment of the farmers to make farming more profitable and dependable. No single farm enterprise is likely to be able to sustain the livelihood of small and marginal farmers without resorting to integrated farming systems (IFS) for the generation of adequate income and gainful employment year round (Mahapatra, 1992;1994). Farming system approach, therefore, is a viable approach to address the problems of sustainable economic growth for farming communities in India.

The basic aim of IFS is to derive a set of resource development and utilization practices which lead to substantial and sustained increase in agricultural production. There exists a chain of interactions among the components within the farming systems and it becomes difficult to deal with such interlinking complex systems. Integrated farming systems are often less risky and, if managed efficiently, benefit from synergisms among enterprises, diversity in produce, and environmental soundness. On this basis, IFS models have been suggested by several workers for the development of small and marginal farms across the country (Rangaswamy et al., 1996; Behera and Mahapatra, 1999)

Integrated Farming System (IFS), a component of Farming System Research (FSR), introduces a change in farming techniques for maximum production in a cropping pattern and take care of optimal utilization of resources. The farm base is better recycling for productive purposes in the integrated farming system. Unlike Specialized Farming System (SFS), integrated farming systems activity is focused around a few selected, inter-dependent, inter-related and often inter-linking production systems based on few crops, animals and related subsidiary professions. Integrated farming system involves the utilization of primary produce and secondary produce of one system as basic input of other system, thus making the mutually integrated as one whole unit. There is a need for effective linkages and complementarities of various components to develop holistic farming system

In order to meet the multiple objectives of poverty reduction, food security, competitiveness and sustainability several researchers have recommended to adopt integrated farming systems (IFS). Integrated farming system is an approach in which different land-based enterprises viz, crop, live stock, mushroom, apiary, fishery etc. are integrated within the bio-physical and socio economic situations taking farmers preference and goal in to consideration. Farming system research/IFS is considered as a powerful tool 
for management of vast natural and human resources in developing countries. This is a multi-disciplinary approach and very effective for solving the problems of small and marginal farmers (Gangwar, 1993).

\section{Characteristics of farming systems}

The Farming System Research (FSR) activities are to be farmer oriented, system oriented, problem solving approach, interdisciplinary, compliments mainstream disciplinary research, test the technology in on-farm trials and provides feedback from the farmers. The strategy of FSR should emphasize that the research agenda should be determined by explicitly defined farmers' needs through an understanding of the exiting farming systems rather than its perception by the researchers. The farming systems research and extension should be dealt in holistic manner on farmer's participatory mode with problem solving approach, keeping genders activity, inter disciplinary and interactive approach. It should emphasize extensive onfarm activities and complement the experimental on-station research and acknowledges the location specificity of technical solutions and document the inter dependencies among multiple clients. Greater importance is placed on feedback to modify the content of subsequent on farm trials, if necessary.

\section{Importance of integrated farming system}

Livelihood of small and marginal farmers, comprising $84 \%$ of total farmers, depends mainly on crops or livestock, which is often affected by weather aberrations. An important consequence of this has been that their farming activities remain, by and large, subsistent in nature rather than commercial and many a time uneconomical. Under present scenario, in the absence of scientifically designed, economically profitable and socially acceptable appropriate integrated farming systems models, they are unable to harness the benefits of integration. Integration of different agriculturally related enterprises with crops provides ways to recycle the products and byproducts of one component as inputs to another and reduce the cost of production and increase the total income of the farm.

\section{Why Farming Systems Research}

During the last 4-5 decades of agricultural research and development in India, major emphasis has been given to component and commodity based research projects for developing crop varieties, animal breeds and farm implements etc, mostly conducted in isolation and at the institute level (Behera et al., 2004). This component, commodity and discipline based research has proved largely inadequate in addressing the multifarious problems of small farmers (Jha, 2003). Due to such approaches, several ills have appeared in Indian farming, such as decreasing factor productivity, resource use efficiency and declining farm profitability and productivity (Sharma and Behera, 2004). Environmental degradation including ground water contamination and entry of toxic substance into the food chain has become a significant problems. To tackle such problems, farming systems approaches to research has been widely recognized.

Farming system refers to particular arrangement of enterprises that are managed in response to physical, biological and socioeconomic environmental factors and in accordance with farmer's goals, preferences and resources. In farming system approach to research the whole farm rather than single farm enterprise is taken into consideration, while decisions are taken for technology adoption and production activities. In this approach the whole farm is viewed as a system and interactions among the various 
components are taken in to consideration (Mahapatra and Behera, 2004) and Mahapatra (2010).

IFS models for important Agro-ecosystems in India

Irrigated

Rainfed / dryland

Coastal Hill \& mountain 4. Desert

\section{Objectives of OFAR}

To reduce the yield gap between the experimental station and farmers' fields

To measure the impact of technology under varying biophysical and socio-economic constraints.

To identify the key components of technology which can help increase farm income

To characterize and quantify the factors responsible for yield gap.

To measure the extent of acceptability of technology by the farmers.

To study the applicability of the technology under wide range of conditions.

To study the stability in production and profitability from a given technology.

To determine the scale neutrality of the technology.

To refine the technology suiting to the local conditions.

To identify and resolve location specific problems through diagnostic survey.

\section{Farming system research focus}

Farmer oriented and System oriented

Problem solving approach

Interdisciplinary

Compliment mains stream

Disciplinary research

Test technology on farm trial

Provides fed back to the farmers

\section{Farming system research step}

Farmer selection

Selection of village and farmer

Diagnosis of constraints in increase the farm productivity

Research design and technology generation and adoption

Technology transfer and diffusion

Impact of technology of improved farming system

\section{Major Focus in Farming Systems}

FSR integrates the following key activities and concepts into a coherent research process designed to overcome the perceived weaknesses in main stream agricultural research.

It is problem solving

FSR is farmer oriented 
FSR is system oriented

FSR is inter disciplinary

FSR complements mainstream commodity and disciplinary agricultural research

On Farm Research is central to FSR approach

\section{Determinants of Farming System}

\section{Key determinants are}

Natural resources (climate, soil, biodiversity)

Natural calamities (Floods, drought, cyclones)

Science \& Technology

Trade liberalization

Market development

Farm size farm resources

Policies

Institutions

Public goods

Human capital

Indigenous Technical Knowledge

Consolidation of holding

Storage \& transport

Road connectivity

Pricing policy

Supply \& Services

Credit input \& technology delivery systems
Components of Integrated Farming System

Crops and Cropping Systems

Food, Fodder, Fiber, Fuel

Pulses, Oilseeds

Fruits, Vegetables, Flowers

Medicinal \& Aromatic plants

Commercial crops (Sugarcane, Spices, Tea, Coffee, Rubber)

Livestock (Cattle, Buffaloes, Goat, Sheep and Pigs) 8.Dairy

Poultry

Duckery

Fishery

Agro forestry

Apiary

Sericulture

Mushroom

Biogas

Main farming system practicing in India

Crop- livestock faming system

Agri- horticulture faming system

Agro-forestry system

Crop-livestock-pastoral system

Mixed farming system 
Sole crop faming system

Rice based farming system

Horticulture based farming system

Livestock based farming system

\section{Integrated farming system goal}

Maximize yield of all comment enterprises to provide steady and stable income

Reducing the use of chemical fertilizer and other harmful chemical and practiced to provide pollution free, healthy produce and environments

Stability in income and enhances standard of living of concerned beneficiary

Optimum resource mobilization and utilization

Factor governing choice and give of enterprises and resource allocation

Climatic condition

Soil type

Size of the farm

Knowledge, skill and technology

Storage, transfer and marketing

Resource mobilization power

Credit facility available

Socio economic condition

Customs, sentiment and believes

\section{Farming system research impacts studies}

Production efficiency

Economics return

Energy input/output

Employments

Equity environment

Sustainability of Agriculture depends upon on the adoption of suitable farming system with inclusion of crop, animal, and the allied enterprise.

Appropriate utilization of human labour, scientific management of available resource and recycling of agricultural work by way of integrating different enterprises will make farming system as profitable business.

Hence, priority on allied enterprises is necessary to increase farm income.

Farming system designate a set of agricultural activities organized while preserving land productivity environmental quality and maintaining desirable level of biological diversity and ecological stability.

\section{Factor affecting IFS}

Soil and climatic feature of the selected

Availability of resource, land, labour and capital

Present level of utilization resource

Economics of proposed IFS

Management skill of farmer 


\section{Advantages of integrated farming systems}

Increased productivity, profitability, and sustainability are ensured with protective food and environmental safety. Recycling of waste material, income round the year, saving energy, meeting fodder crisis, employment generations and ultimately increasing the standard of living of the farmers are other major benefits of integrated farming systems.

Integrated farming system has the advantages of increasing economic yield per unit area per unit time, profitability, sustainability and provides balanced nutritious food for the farmers, pollution free environment and provide opportunity for effective recycling of one product as input to other component, money round the year and solve the energy, fodder, fuel and timber crisis, avoids degradation of forests and enhance the employment generation, increase input use efficiency and finally improve the livelihood of the farming community.

Crop based farming systems: The guiding principles for selection of crops and varieties for efficient management of resources in rainfed areas are: land use capability concept, water availability concept, crop substitution, quantity and distribution of rainfall, soil depth and performance of crops. Effective growing period concept is mostly used in deciding cropping systems in different agro-climatic zones.

Integrated farming system - A way to sustainability

In Integrated farming System, organic supplementation through effective utilization of residues / waste of linked components as manures. In addition vermicormposting constitutes an essential component of Integrated Farming System, thereby IFS helps to maintain sustainable status of soil fertility in terms of physical, chemical and micro biological properties.

Migration of rural poor and agricultural labors could be solved by integrating allied appropriated components in different eco zones as situated to varied resource situation.

The rural and farm women falling under small and marginal categories as well as Agricultural landless laborers will be benefited through the regular employment by integrated farming system.

The integration of small ruminants and buffaloes, agro forestry and Silvi-pastoral system along with cropping provide good scope for livelihood

Optimal crop and livestock mixture consistent with the farm resources immediately available provides an opportunity to increase profitability and regular flow of income

Integrated farming system meets spread out demand for food, income and diverse requirements of food grains, vegetables, milk, egg, meat etc. thereby improving the nutrition of small - scale farmers with limited resources.

\section{Successful integrated farming systems}

In the last three decades Scientists at TNAU have conducted several research programmes addressing various facets of integrated farming systems and developed various model wet land, upland irrigated and dry land model and these models are presented here. wetland ecosystem (1.00ha)- Cropping (0.75ha)+Fodder Crop (0.12ha) + Fishery (1000nos.) + Goat (20 female +1 male) Vermicompost (4t production Capacity)

Integration of crop with fish, poultry, pigeon and goat resulted in higher productivity than cropping alone under lowland. Crop + fish + goat integration recorded higher rice grain 
equivalent yield of $39610 \mathrm{~kg} / \mathrm{ha}$ than other systems. Similarly, as an individual animal component, the goat unit $(20+1)$ gave the highest productivity of $8818 \mathrm{~kg}$. This could also provide $11.0 \mathrm{t}$ of valuable manure apart from supplementing the feed requirement of 400 numbers of fish. The highest net return of Rs. 131118 and per day return of Rs. $511 \mathrm{ha}^{-1}$ were obtained by integrating goat + fish + cropping applied with recycled fish pond silt enriched with goat droppings.

The employment opportunity was also increased to 576 man days ha $^{-1}$ year $^{-1}$ by integrating fish + goat in the cropping as against cropping alone (369 man days ha-1 year-1). Irrigated upland ecosystem (1.00ha)Cropping $(0.70 \mathrm{ha})+$ milch cows $(3+2)+$ Goat $(10$ female +1 male $)+$ Vegetables $(0.06 h a)+$ Fodder Crop (0.20 ha) + Vermicompost (6t production Capacity)

The highest productivity of $23328 \mathrm{~kg}$. acre-1 as maize grain equivalent yield, net return of Rs. 64125 /acre' employment generation of 235 man days /acre were obtained by integrating dairy, goat, guinea fowl, Vermicompost and cropping applied with recycled manure to the first crop in the system and were higher than the traditional farming system. In addition, 7.83 tonners per acre of crop and animal residues could be recycled through effective recycling.

Dry land eco system (1.00 ha)- silivepasture (Cenchrus setigerus + Stylosanthes hamata $\&$ fodder sorghum + Pillipesara) + Sheep $(5+1)+$ buffalo (2 No.'s) + Vermicompost (5t production Capacity) + farm pond

Cenchrus setigerus + Stylosanthes hamata \& fodder sorghum + Pillipesara system with sheep (5+1) and buffalo (2No.'s) was promising, which generated the highest system productivity of $67660 \mathrm{Kg}$ of Cenchrus equivalent yield with net return of $32485 /$ ha /year and benefit cost ratio of 2.58 with an employment opportunity of 169 man days/ ha/ year.

\section{Integrated farming systems in single objective frame work}

Decision making is the most important aspect of any business and industry. Farming is a business and agriculture is also an industry. Hence, decision making plays an important role with regard to the problems concerning production of commodities. The main questions before the producer or the production manager/farmer are:

what to produce,

How to produce, and

How much to produce. In a integrated farming system, farmers face the similar problems with respect to production of different commodities/enterprises at the farm level. Linear programming is a modeling tool that can assist in the solution of may problems in agriculture. In particular linear programming is useful in selection the best alternative from a number of available course of action. LP model are designed to "optimize" a specific objective criterion subject to a set of constraints, the quality of the resulting solution depends on the completeness of the model in representing the real system.

\section{Integrated farming systems in multi- objectives frame work.}

In real world IFS situation farmers face the difficulty of considering several objectives simultaneously, which are confliction in nature such as farm return, capital requirement and labour employment. In addition farmers like to produce enough food for the farm family by utilizing his resources effectively including land. 
Table.1 Production of food and forage crops and income from IFS unit and conventional system

\begin{tabular}{|c|c|c|c|c|c|c|}
\hline \multirow[t]{2}{*}{ SI.No } & \multirow{2}{*}{$\begin{array}{c}\text { Area } \\
\text { ha }\end{array}$} & \multirow[t]{2}{*}{ Yield (t) } & \multirow{2}{*}{$\begin{array}{c}\text { Sale price } \\
\text { /t } \\
(\mathrm{Rs})\end{array}$} & \multirow{2}{*}{$\begin{array}{c}\text { Cost of } \\
\text { Cultivatio } \\
\text { n } \\
(\text { Rs })\end{array}$} & \multicolumn{2}{|c|}{ Returns (Rs) } \\
\hline & & & & & Gross & Net \\
\hline \multicolumn{7}{|c|}{ Integrated Farming System Unit } \\
\hline \multicolumn{7}{|c|}{ Field crops } \\
\hline Kharif - Rice & \multirow[t]{3}{*}{0.24} & 1.6 & 15000 & 6000 & 24000 & 18,000 \\
\hline Rabi - Sweet corn & & 18,000 cobs & $3 / \mathrm{cob}$ & 24000 & 54000 & 30,000 \\
\hline Summer- Dhaincha & & Ploughed in situ & & & & \\
\hline Fruit crop - Banana & 0.15 & 11.5 & 5000 & 16600 & 57500 & 40900 \\
\hline \multicolumn{7}{|l|}{ Vegetable crops } \\
\hline Kharif - Brinjal & \multirow[t]{2}{*}{0.2} & 2.0 & 12000 & 10,000 & 24,000 & 14,000 \\
\hline Rabi - Tomato & & 2.0 & 20,000 & 20,000 & 40,000 & 20,000 \\
\hline \multicolumn{7}{|l|}{ Others } \\
\hline Coconuts & Bunds & 2,500 nuts & 10 per nut & $8,500^{*}$ & $25,000 *$ & $16,500^{*}$ \\
\hline Field beans & Bunds & 0.6 & 30000 & 3,000 & 18,000 & 15,000 \\
\hline Bottle gourd & 0.04 & 200 fruits & $10 /$ fruit & 500 & 2,000 & 1,500 \\
\hline Bitter gourd & & 0.165 & 30,000 & 1,000 & 4,950 & 3,950 \\
\hline Drumstick & 20 plants & 400 pods & 2/pod & - & 800 & 800 \\
\hline Total & 1.76 & & & 89600 & 250250 & 160650 \\
\hline \multicolumn{7}{|l|}{ Fodder production } \\
\hline \multicolumn{7}{|c|}{ Annual crops (Roughages) } \\
\hline Rice straw & 0.24 & 2.0 Hay & & & & \\
\hline Sweet corn stover & 0.24 & $\begin{array}{l}6.0 \text { moist } \\
(2 t \text { dry })\end{array}$ & & & & \\
\hline $\begin{array}{l}\text { Fodder Jowar Green- } \\
\text { kharif and rabi }\end{array}$ & 0.06 & $4.0+3.0$ & & & & \\
\hline $\begin{array}{l}\text { Fodder maize Green- } \\
\text { kharif and rabi }\end{array}$ & 0.06 & $4.0+3.0$ & & & & \\
\hline \multicolumn{7}{|l|}{ Perennial crops } \\
\hline \multicolumn{7}{|l|}{$\begin{array}{l}\text { Hybrid Napier green } \\
\text { grass (Roughage) }\end{array}$} \\
\hline Variety Co 4 & 0.06 & 12.0 & & & & \\
\hline Variety Co 5 & 0.06 & 12.0 & & & & \\
\hline \multicolumn{7}{|l|}{ Legumes } \\
\hline Lucerne & 0.12 & 20 & & & & \\
\hline \multicolumn{7}{|c|}{ Conventional cropping system } \\
\hline Kharif-Rice & 1.0 & 7.23 & 15000 & 55350 & 108450 & 53100 \\
\hline \multirow[t]{2}{*}{ Rabi- Maize } & 1.0 & 8.18 & 13500 & 25157 & 110430 & 85273 \\
\hline & & & & 80507 & 218880 & 138373 \\
\hline
\end{tabular}

Note: Income from coconut will commence after 3 years* 
Table.2 Cost of production and income from livestock

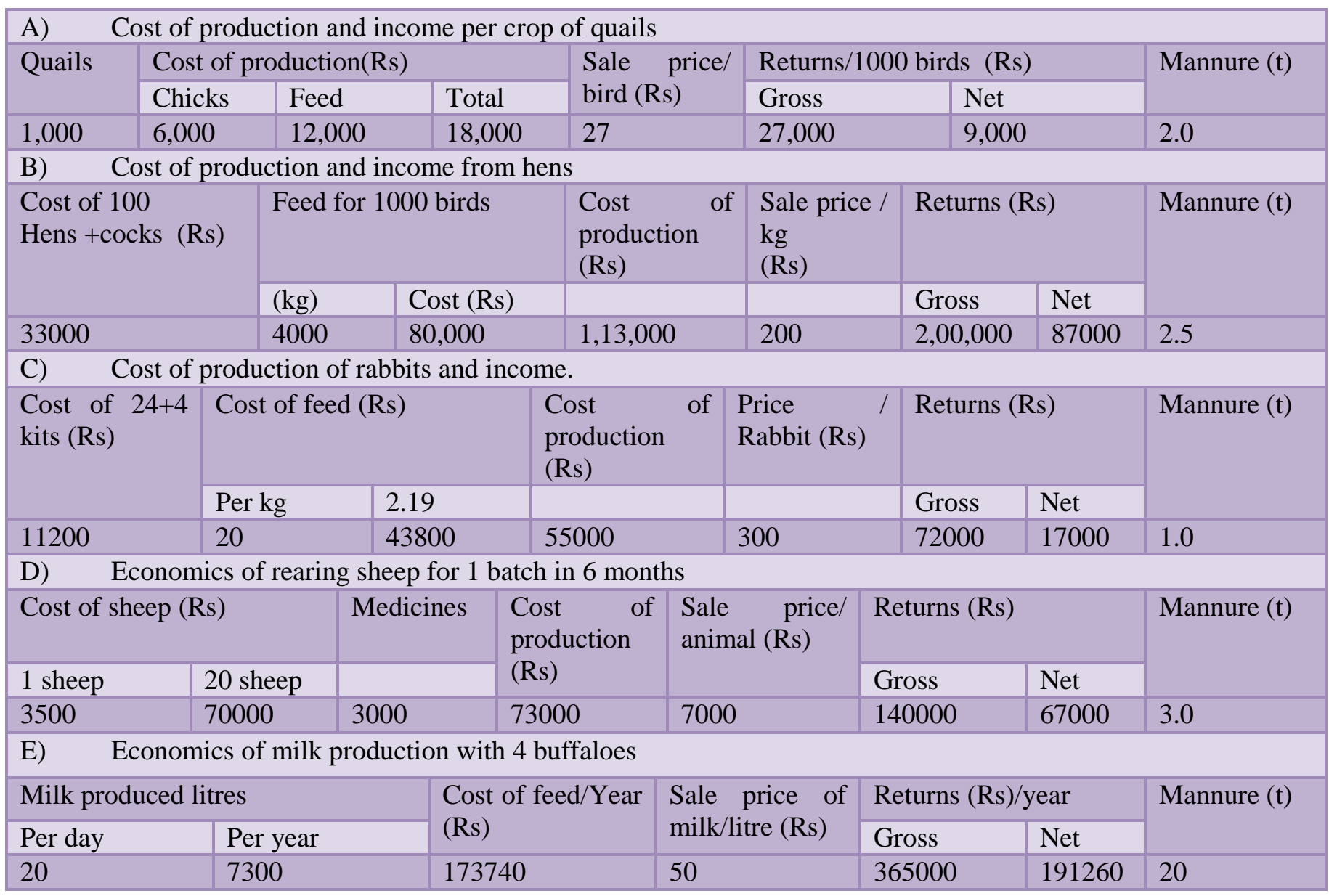

Table.3 Cost of production and income from the components of IFS unit and conventional system

\begin{tabular}{|c|c|c|c|c|}
\hline \multirow[t]{2}{*}{ S.No. } & \multirow[t]{2}{*}{ Component } & \multirow[t]{2}{*}{ Cost of production (Rs) } & \multicolumn{2}{|l|}{ Returns (Rs) } \\
\hline & & & Gross & Net \\
\hline \multicolumn{5}{|c|}{ Integrated Farming System } \\
\hline 1 & Crops & $89,600.00$ & $2,50,250.00$ & $1,60,650.00$ \\
\hline 2 & Dairy & $1,73,740.00$ & $3,65,000.00$ & $1.91,260.00$ \\
\hline 3 & Sheep & $73,000.00$ & $1,40,000.00$ & $67,000.00$ \\
\hline 4 & Rabbits & $55,000.00$ & $72,000.00$ & $17,000.00$ \\
\hline 5 & Hens & $1,13,000.00$ & $2,00,000.00$ & $87,000.00$ \\
\hline 6 & Quails & $1,44,000.00$ & $21,6000.00$ & $72,000.00$ \\
\hline 7 & Manure & & & $14,250.00$ \\
\hline \multicolumn{2}{|c|}{ Total Rs. } & $6,48,340.00$ & $12,43,250.00$ & $6,09,160.00$ \\
\hline \multicolumn{5}{|c|}{ Conventional system (Rice-Maize) } \\
\hline 8 & Rice & 55350 & 108450 & 53100 \\
\hline 9 & Maize & 25157 & 110430 & 85273 \\
\hline \multicolumn{2}{|c|}{ Total Rs. } & 80,507 & $2,18,880$ & $1,38,373$ \\
\hline
\end{tabular}


For this, compromise programming method can be effectively employed for achieving a practical and compromise solution in such situation (Behera et al., 2008).

In the traditional mathematical programming approach to modeling agricultural decision making, the decision maker seeks to optimize a well-defined single objective. In reality, this is not always the case as the decision maker is often seeking an optimal compromise among several objectives, many of which can be in conflict, or trying to achieve satisfying levels of his goals (Romeo \& Rehman 1989). Two multi-criteria programming techniques, goal programming and programming techniques, goal programming and compromise programming (both variants of linear programming), were used in a study of smallscale dairy farms in central Mexico by ValArreoal et al., (2006). Compromise Programming (CP) is used to provide more insight into the problem which caters multiobjective needs of the farmers. Linear and nonlinear programming methodologies can be employed in environment to draw different scenarios' for comparison. This enables in developing holistic model. Compromise programming methodology has been demonstrated for designing integrated farming system (Behera et al., 2008).

An one ha model of integrated farming system at Agricultural Research Institute, Rajendranagar, Hyderabad,. One hectare area divided into 5 blocks viz. involving rice-sweet corn- dhaincha on 0.24 ha, banana plantation with on 0.15 ha, brinjal-tomato in 0.2 ha for vegetable production, Green fodder crops were raised on 0.35 ha. 50 saplings of coconut were planted all around the bunds. Field beans are also grown on the bunds between the trees of coconut. Vines of bitter gourd, bottle gourd and cucumber were trained on a pandal of 0.04ha. A shed consisting 7 compartments was built with required facilities over an area of
0.016 ha to accommodate with 4 buffaloes, 4 calves, 20 sheep, 34 rabbits, 110 hens and 1000 quails and farm family in each. This model was compared with predominant cropping system of the area i.e. Rice-Maize in one hectare. Gross and net returns of Rs $12,43,250$ and Rs 6,09,160 were realised respectively from one ha model during first year. Where as in Rice-Maize crop sequence, gross and net returns were Rs 2,18,880 and $1,38,373$ respectively. Integrated farming System could generate 750 man days $\mathrm{ha}^{-1}$ annum $^{-1}$ which is 3 times higher than ricemaize (225 man days) cropping system.

\section{References}

Annual Reports, 2016\&2017 of AICRPIFS,Rajendranagar,Hyderabad,Andhra Pradesh

Behera, U.K. and Mahapatra, I.C. 1999. Income and employment generation of small and marginal farmers through integrated farming systems. Indian Journal of Agronomy 44(3): 431-439.

Behera, U.K., Jha, K.P. and Mahapatra, I.C. 2004. Crop Research 27 (1): 83-89.

Behera, U.K., Yates, C.M.Kebreab, E. and France, J. 2008. Farming systems methodology for efficient resource management at the farm level: an Indian perspective. Journal of Agricultural Sciences, Cambridge 146: 493-505

Gangwar, B. 1993. Farming systems research for accelerating agricultural development in less developed countries - A Review. Agricultural Reviews 14(3): 149-159.

Jayanti.C. 2014. Agriculture diversification : A better option to improve soil fertility and productivity through integrated farming system. Extended summaries of lead papers A national symposium on agriculture 
diversification for sustainable livelihood and environmental security. Nov.18-20,2014,PAU,Ludhiana,25-27.

Jha, D. 2003. An overview of farming systems research in India. Annals of Agricultural Research 24: 695-706.

Mahapatra, I.C. 1994. Farming system research - Akey to sustainable agriculture. Fertilizer News. 39 (11): 13-25

Mahapatra, I.C. and Behera, U.K. 2004. Methodologies of farming system research. (Panda, D., Sasmal, S., Nayak, S.K., Singh, D.P. and Saha, S. eds.. "Recent advances in Rice-based Farming systems", 17-19 November, 2004, Cuttack, Orissa, Central Rice Research Institute. Pp. 79-113.

Mahapatra, I.C. 2010. Manual on integrated farming systems, Proceeding of launching workshop of integrated farming systems during Group meeting of scientist of AICRP on IFS held at Thiruanantpuram, Kerala, 6-9 March, 2010. PDFSR, Modipuram, Meerut, 250110. Policy and methodological issues Read map and strategy for Integrated Farming
Systems Research in India.

Rangaswamy, A, Venkataswamy, R., Premsekhar, M. and Palaniappan, S.P., 1992. Sustainable agriculture for rice (Oryza sativa) based ecosystem, Indian Journal of Agronomy 37 (2): 215- 219.

Romero, C. and Rehman, T. 1989. Multiple Criteria Analysis for Agricultural Decisions. Amsterdam: Elsevier.

Singh, G. 2005. Farming systems options for sustainability of natural resources. (In:) Proceedings of Symposium on "Alternative Farming Systems: Enhanced income and employment generation options for small and marginal farmers". (Eds. A.K. Singh, B.Gangwar and SK Sharma), FSR held at Project Directorate for Cropping systems Research, Modipuram from 16-18

September, 2004, p. 57-64.

Singh Gurbachan 2014. Agriculture diversification for food,nutritional and environmental security. Souvenir: A national symposium on agriculture diversification for sustainable livelihood and environmental security. Nov.18-20,2014,PAU,Ludhiana,13-16.

\section{How to cite this article:}

Tejeswara Rao, K., M. M. V. Srinivasa Rao and Patro, T. S. S. K. 2019. AICRP on Integrated Farming Systems, Agricultural Research Station, Vizianagaram, AP, India .

Int.J.Curr.Microbiol.App.Sci. 8(09): 2629- 2642.

doi: https://doi.org/10.20546/ijcmas.2019.809.304 